ACTA UNIVERSITATIS NICOLAI COPER NICI DOI: http://dx.doi.org/10.12775/AUNC_ECON.2015.003 EKONOMIA XLVI nr 1 (2015) 77-95

Pierwsza wersja złożona 23 października 2015

e-ISSN: 2392-1269

Końcowa wersja zaakceptowana 28 grudnia 2015

Sylwester Bejger*

\title{
INVESTIGATION \\ OF THE NATURE OF STRATEGIC INTERACTIONS \\ IN THE POLISH WHOLESALE FUEL MARKET: STATISTICAL ANALYSIS OF A MARKET STRUCTURE AND A PRICE MECHANISM
}

\begin{abstract}
A b stract. The study is devoted to preliminary analysis of the Polish petroleum industry and the wholesale level of the fuel market in the context of strategic interactions' research. In the paper, the structure of the Polish petroleum industry (refining sector) and the wholesale level of the market were analyzed, in order to extract every factors influencing the shape of theoretical strategic interaction model. As a result, the key characteristics of the industry, the wholesale market, the players and price creation mechanism have been isolated. Basing on that findings, the Author has pointed to essential elements of the theoretical model of strategic interactions (game model), which can be constructed as a possible model of players' behavior.

K e y w o r d s: wholesale fuel market, strategic behavior, descriptive statistics.
\end{abstract}

J E L C 1 a s s if i c a ti o n: L1, L7, C41.

\footnotetext{
* Correspondence to Sylwester Bejger, Nicolaus Copernicus University, Department of Econometrics and Statistics, ul. Gagarina 13A, 87-100 Toruń, Poland, e-mail: sylw@umk.pl.

(C) 2015 Uniwersytet Mikołaja Kopernika. All rights reserved. http://www.aunc.ekonomia.umk.pl
} 


\section{INTRODUCTION}

One of the most important tasks for economics (and the economists) in antitrust litigations is delivering credible procedures or methods which could allow for distinguishing between a competitive and uncompetitive conduct without exact knowledge of players' private information. For the main stream of industrial organization (see for example Tirole, 1988), one can state that for a given market characteristics, the player's strategies describe their behavior. If such an assumption is taken, various quantitative methods of detection and measurement of anticompetitive behavior could be developed. One strand of the research is the development of the so called markers of anticompetitive (mostly horizontally collusive) behavior which are utilized within a screening procedure ${ }^{1}$. Another path is based on an estimation and assessment of a market power, residual demand's estimation or direct estimation of players' strategies. This path encompasses various models and methods ${ }^{2}$. Regardless of the method, every study which is aimed at delivering evidence of potential distortions of competition should contain, as the first step, a study of main structural parameters of an industry (market), the main players and the strategic interactions which take place. Abrantes-Metz (2013) and Abrantes-Metz (2011), while developing econometric (behavioral) screening methods, emphasized that good, reliable screen, among others, should be 'based on deep understanding of an industry, nature of competition and motivations to anticompetitive behavior'.

She also stated, as a rule of thumb in screen's constructions, that "one size does not fit all", which means that even if some typical theoretical models of strategic behavior associated with quantitative markers can be isolated, every industry and market should be treated independently, and examined for the main structural parameters. The present paper contains such a study, considered as the first, necessary step of an assessment of a strategic behavior of the players in the Polish wholesale fuel market ${ }^{3}$. The paper consists of an introduction and 4 sections. Section 1 contains a brief description of the Polish refining industry and major players. Section 2 concentrates on the analysis of relevant level of the domestic fuel market. Section 3 investigates

\footnotetext{
${ }^{1}$ For a comprehensive overview see: Harrington (2008), Abrantes-Metz (2011).

${ }^{2}$ Bejger (2009) contains a list of various tools, market power estimation is deeply studied in Perloff, Karp and Golan (2007).

${ }^{3}$ On the basis of that research, the Author was able to develop a theoretical model of strategic price interactions and econometrically verify some of the behavioral patterns which have been inferred on the basis of an industry study and a theoretical model.
} 
the mechanism of creation of the wholesale prices. Section 4 concludes the paper.

\section{POLISH PETROLEUM INDUSTRY}

The time frame of study encompasses the period from 01.01.2004 to 31.12.2013, and this time window was taken as relevant for all important market characteristics.

At first, one has to highlight macroeconomic environment of the industry. Since the beginning of the 90s, Poland has been one of the leading economies in Central and Eastern Europe. According to the data from Eurostat, Poland was also the only country in the European Union whose real GDP grew each year from 2002 to 2013. In 2011, according to Eurostat, real GDP grew to $4.5 \%$, compared with the average growth in the European Union, which amounted to $1.6 \%$. In 2012 the real Polish GDP growth was $2.0 \%$, compared to the average decline in the European Union, which amounted to $0.4 \%$. However, in 2013 the real Polish GDP growth reached $1.6 \%$, compared to the average growth of $0.1 \%$ for the whole of the European Union. In 2013, Poland was the eighth country in terms of real GDP growth on an annual basis, in comparison with other countries of the European Union. The situation in the Polish market of liquid fuels followed the general macroeconomic condition of Poland, but intra-market parameters were no less important. The total consumption of liquid fuels in Poland was reduced in 2011-2013. According to estimates of the $\mathrm{POPiHN}^{4}$, the total liquid fuel consumption (including motor gasoline, diesel fuel (excluding marine fuel), LPG, jet fuel, and light and heavy fuel oil) amounted to 24.9 million $\mathrm{m}^{3}$ in 2013, and was 3.4\% lower than in 2012, while in 2012 it amounted to 25.8 million $\mathrm{m}^{3}$, and was $6.3 \%$ lower than in $2011^{5}$. Diesel motor oil ${ }^{6}$ continued

\footnotetext{
${ }^{4}$ Polska Organizacja Przemysłu i Handlu Naftowego - The Polish Oil Industry and Trade Organization is an employers' organization, consisting of the largest Polish companies in the area of production and distribution of liquid fuels, fuel infrastructure and the production and distribution of lubricating oils.

${ }^{5}$ Statistical data on liquid fuels are expressed in many different units. In this article every effort was made to unify the unit to kilo tons $(\mathrm{kt})$ or cubic meter $\left(\mathrm{m}^{3}\right)$. Unfortunately, for aggregated data, conversion to another unit than the original one is often impossible due to different conversion factors for different fuels. Thus, consumption for fuels is interchangeably expressed in the text in $\mathrm{m} 3$ or $\mathrm{kt}$.

${ }^{6}$ As there are various fuel products with the words "diesel oil" in the name (heavy marine diesel oil, for example) a product in interest have to be precisely defined. As diesel oil, or diesel in short, we understand unbranded diesel oil for road transport with $10 \mathrm{ppm}$ sulphur content.
} 
to be the most widely used liquid fuel in Poland, and its share in domestic consumption in 2013 was about $60 \%$. In 2013, the Polish market of motor gasoline ${ }^{7}$ reflected the trends occurring in other parts of Europe, and continued to decline. The demand for motor gasoline, according to the POPiHN 2013 , fell by almost $2.2 \%$ (i.e. about 111 thousand. $\mathrm{m}^{3}$ ) compared to 2012 , to the level of 4.9 million $\mathrm{m}^{3}$. The decline in demand for fuel is caused by the economic slowdown, high retail prices and undisclosed gray market imports. More details on gasoline and diesel motor oil supply and demand are provided further in the text.

\subsection{MAJOR PLAYERS' CHARACTERISTICS}

The refining sector in Poland is dominated by two companies: Orlen

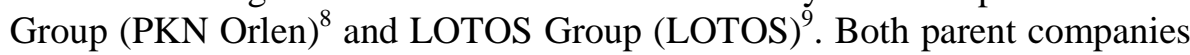
are partly owned by the state treasury, which holds a $27.5 \%$ stake in PKN Orlen and a 53.2\% stake in Grupa LOTOS, but in fact no strategic decision is possible to make without an approval of the Polish government. PKN

\footnotetext{
${ }^{7}$ Motor gasoline (or a gasoline in short) has been defined as unbranded unleaded 95 octane gasoline with $10 \mathrm{ppm}$ sulphur content.

${ }^{8}$ PKN Orlen is the main member of the ORLEN Group. ORLEN Group comprises PKN ORLEN (the Parent) and various companies based in Poland, Germany, the Czech Republic, Lithuania, Malta, Sweden, the Netherlands, Slovakia, Switzerland, Estonia, Latvia and Canada. In December 31st 2013, PKN ORLEN held, directly or indirectly, shares in 90 companies, including: 78 subsidiaries, 7 jointly-controlled entities, and 5 associated entities. The refining sector of the group consists of two foreign facilities, ORLEN Lietuva (10.2 mln tones of annual capacity) and Unipetrol a.s. ( $8.7 \mathrm{mln}$ tones of annual capacity) and three domestic facilities: main refinery located in Płock and two small refineries: Trzebinia Refinery and Jedlicze Refinery (360 and 90 kilo tones of capacity respectively). Because our relevant market is a domestic one, and the two small refineries of Orlen Group are not important in terms of fuel's production and wholesaling (they specialize chiefly in fuel storage and distribution services, production of biocomponents, base oils and fuel oils, as well as regeneration of spent oils) the Author concentrated on Płock Refinery as the major player in refining, and all production data are valid for this refinery. It was decided, in order to avoid complication, to name the player representing Orlen group in domestic market as PKN Orlen (or PKN in short), but one has to remember that this name, in the context of this paper, means Płock's refinery, and all those parts of PKN Orlen which are involved in the activities in the Polish wholesale or retail market.

${ }^{9}$ LOTOS Group comprises Grupa LOTOS S.A. (the parent entity and operator of the refinery in Gdańsk) and 22 production and service companies, including: 13 direct and 9 indirect subsidiaries of Grupa LOTOS. Two of them are based outside Poland, in Lithuania and Norway. It was decided, in order to avoid complication, to name the player representing LOTOS Group in domestic market as LOTOS, but one has to remember that this name, in the context of this paper, means the refinery located in Gdańsk and all those parts of Grupa LOTOS S.A. which are involved in the activities in the Polish wholesale or retail market.
} 
is the owner of Poland's largest refinery located in Płock (Central Poland), which is supplied directly by the crude oil pipeline 'Druzhba', while LOTOS owns the second largest refinery located in Gdańsk, which can be supplied by a side-leg of the 'Druzhba' pipeline or from the Baltic Sea. Both refineries have a high value of Nelson complexity index (9.5 and 10), which means that both of them are capable of complex refining of crude ${ }^{10}$, which contributes to a significantly greater flexibility in the products produced. This greater flexibility enables complex refineries to vary their product mix to take advantage of movements in prices and improve their profitability.

Table 1 provides a detailed overview of the Polish refinery industry in terms of production capacities of the mayor players. In the period of interest, the capacities of both players increased systematically and reached the grow rate of $21 \%$ in the case of PKN, and $133 \%$ in the case of LOTOS in the sample period. Capacity utilization was very high in the case of both players (on average $96 \%$ and $94 \%$, respectively), despite the investments, so it can be said that the production of both players was capacity - limited. One should notice that such trends are at odds with the European tendencies where, since 2009, several refineries, with a combined processing capacity of $3.7 \mathrm{~m} \mathrm{bbl} / \mathrm{d}$, have been closed down. This scaling back still seems insufficient, as many European refineries continue to generate low returns, with their processing capacities still relatively underutilized (the average refining capacity utilization in Europe was $71 \%$ in October 2013$)^{11}$. The players' market shares in terms of processed crude are roughly in the proportion of $2 / 3$ to $1 / 3$ at present, due to LOTOS's higher capacity build up. HHI index of refining has declined a bit since the beginning of the sample, but is still very high $^{12}$. For comparison, Central and Eastern Europe region HHI of complex capacity in 2009 was equal to $0.1624^{13}$.

\footnotetext{
${ }^{10}$ Complex refining involves a combination of interrelated processes, such as thermal and catalytic cracking, coking and deep conversion of the crude oil feedstock.

${ }^{11}$ Integrated Annual Report 2013 - Grupa LOTOS S.A.

${ }^{12}$ In general, an assessment of the value of an HHI index should be market-specific and depend on the purpose of its calculation. As a point of reference for its values in a sense of degree of concentration, the US Department's of Justice merger guidelines are often used, where the value of HHI Index greater than 0,180 indicates high market concentration.

${ }^{13}$ Report DGET (2009), p. 42.
} 
Table 1. Capacities and its utilization

\begin{tabular}{cccccccccccc}
\hline \multicolumn{2}{c}{$\begin{array}{c}\text { crude } \\
\text { distilla- } \\
\text { tion } \\
\text { capacity } \\
\text { (kt) }\end{array}$} & $\begin{array}{c}\text { crude } \\
\text { proces- } \\
\text { sed (kt) }\end{array}$ & $\begin{array}{c}\text { capacity } \\
\text { utilisa- } \\
\text { tion }\end{array}$ & $\begin{array}{c}\text { crude } \\
\text { distilla- } \\
\text { tion } \\
\text { capacity } \\
\text { (kt) }\end{array}$ & $\begin{array}{c}\text { crude } \\
\text { proces- } \\
\text { sed (kt) }\end{array}$ & $\begin{array}{c}\text { capacity } \\
\text { utilisa- } \\
\text { tion }\end{array}$ & $\begin{array}{c}\text { crude } \\
\text { proces- } \\
\text { sed (kt) }\end{array}$ & \multicolumn{3}{c}{$\begin{array}{c}\text { crude processing market } \\
\text { share }\end{array}$} \\
\hline Year & PKN & PKN & PKN & LOTOS & LOTOS & LOTOS & Others* & PKN & LOTOS & $\begin{array}{c}\text { HHI of } \\
\text { pro- } \\
\text { cessing }\end{array}$ \\
\hline 2004 & 13500 & 12194 & $90 \%$ & 4500 & 4744 & $105 \%$ & 1169 & 0.67 & 0.26 & 0.522 \\
2005 & 13500 & 12570 & $93 \%$ & 6000 & 4837 & $81 \%$ & 760 & 0.69 & 0.27 & 0.550 \\
2006 & 13800 & 13612 & $99 \%$ & 6000 & 6099 & $102 \%$ & 332 & 0.68 & 0.30 & 0.554 \\
2007 & 13800 & 13646 & $99 \%$ & 6000 & 6156 & $103 \%$ & 336 & 0.68 & 0.31 & 0.553 \\
2008 & 14100 & 14218 & $101 \%$ & 6000 & 6203 & $103 \%$ & 380 & 0.68 & 0.30 & 0.556 \\
2009 & 14300 & 14526 & $102 \%$ & 6000 & 5462 & $91 \%$ & 315 & 0.72 & 0.27 & 0.584 \\
2010 & 15100 & 14452 & $96 \%$ & 9452 & 8096 & $86 \%$ & 294 & 0.63 & 0.35 & 0.526 \\
2011 & 16000 & 14547 & $91 \%$ & 10016 & 9165 & $92 \%$ & 289 & 0.61 & 0.38 & 0.513 \\
2012 & 16300 & 15191 & $93 \%$ & 10500 & 9674 & $92 \%$ & 289 & 0.60 & 0.38 & 0.513 \\
2013 & 16300 & 15182 & $93 \%$ & 10500 & 8703 & $83 \%$ & 418 & 0.62 & 0.36 & 0.519 \\
\hline
\end{tabular}

*There were 3 independent refineries, beside Orlen Group and Lotos Group in 2004: Czechowice Refinery, Jasło Refinery and Glimar Refinery. Glimar refinery stopped crude processing in 2005. From 2009 the data in a column Others replicate processing of two small facilities, Trzebinia Refinery and Jedlicze Refinery belonging to Orlen Group.

Source: PKN Orlen 2013 Factbook, own calculations.

Table 2 contains basic data for characterization of the fuel marketat the country level for two products of interests, specifically. One should understand that if aggregate data on the national level are easily obtainable, the players' specific data are more difficult to obtain. However, it was possible to extract from various sources the domestic production's data for PKN and LOTOS for gasoline and diesel. They have been used in wholesale market descriptions further in the text. One can see from Table 2 that the Polish market follows the international-wide trend of substitutions of gasoline by diesel motor oil. The official market was growing systematically from 2004 to 2011 with the average growth rate of $6.3 \%$ (with the exception of 2009), and started to shrink in the last two years. By visual inspection (Figure 1) and basic calculations, it can be determined that diesel production of both players loosely follows the consumption (correlation coefficients of 0.52 and 0.49 for PKN, LOTOS), and there is no such clear dependency in the case of gasoline (correlation coefficients of $0.24,0.50$ ). Interestingly, the productions of both players have changed unidirectional in the case of diesel (correlation 0.50) and acyclically in the case of gasoline (correlation coefficient $(-0.39))$. It is worth noting that the strongest correlation is between LOTOS 
gasoline and diesel indices (0.91). As it can be explained on the basis of Table 1 and LOTOS' capacity investments - additional capacity should be exploited fully for all types of products, especially when relevant market reactions (domestic one in this case) are not binding. To complete an outline of the supply - demand situation in the fuel's market, one should look at the net balance of international trade's figures ${ }^{14}$. As can be seen, domestic gasoline supply has fulfilled the domestic demand almost completely to 2009 and was slightly greater then. In the case of diesel, there was clearly a different situation till 2012, with significant domestic underproduction of that kind of fuel.

Table 2. Basic data of the fuel market for two main products at country level

\begin{tabular}{|c|c|c|c|c|c|c|c|c|c|c|c|}
\hline & \multicolumn{2}{|c|}{$\begin{array}{l}\text { domestic } \\
\text { consumption } \\
\text { (kt) }\end{array}$} & \multicolumn{2}{|c|}{$\begin{array}{l}\text { production } \\
\text { PKN (kt) }\end{array}$} & \multicolumn{2}{|c|}{$\begin{array}{l}\text { production } \\
\text { LOTOS (kt) }\end{array}$} & \multicolumn{2}{|c|}{$\begin{array}{c}\text { domestic } \\
\text { production } \\
(\text { LOTOS + } \\
\text { PKN, (kt)) }\end{array}$} & \multicolumn{2}{|c|}{$\begin{array}{l}\text { net balance of } \\
\text { int. trade }\end{array}$} & \multirow[t]{2}{*}{ share ${ }^{\star \star}$} \\
\hline Year & $\begin{array}{l}\text { Gaso- } \\
\text { line }\end{array}$ & Diesel & $\begin{array}{l}\text { Gaso- } \\
\text { line }\end{array}$ & Diesel & $\begin{array}{l}\text { Gaso- } \\
\text { line }\end{array}$ & Diesel & $\begin{array}{l}\text { Gaso- } \\
\text { line }\end{array}$ & Diesel & $\begin{array}{l}\text { Gaso- } \\
\text { line }\end{array}$ & Diesel & \\
\hline 2004 & 4116 & 6481 & 2753 & 3347 & 1216 & 1258 & 3969 & 4605 & 283 & 1326 & $15 \%$ \\
\hline 2005 & 4008 & 7246 & 2861 & 3521 & 952 & 1190 & 3813 & 4711 & -62 & 1670 & $14 \%$ \\
\hline 2006 & 4144 & 8222 & 2723 & 3995 & 1418 & 2226 & 4141 & 6221 & 387 & 2253 & $21 \%$ \\
\hline 2007 & 4161 & 9532 & 2610 & 4568 & 1346 & 2607 & 3957 & 7175 & 478 & 3503 & $29 \%$ \\
\hline 2008 & 4197 & 10518 & 2800 & 5078 & 1246 & 2920 & 4046 & 7998 & 405 & 3408 & $26 \%$ \\
\hline 2009 & 4272 & 10387 & 3055 & 5330 & 1282 & 3225 & 4337 & 8555 & 242 & 3456 & $25 \%$ \\
\hline 2010 & 4222 & 11717 & 2736 & 5359 & 1425 & 4050 & 4161 & 9409 & -51 & 2662 & $16 \%$ \\
\hline 2011 & 3999 & 12259 & 2469 & 5646 & 1375 & 4661 & 3844 & 10307 & 54 & 2614 & $16 \%$ \\
\hline 2012 & 3795 & 11772 & 2491 & 5829 & 1442 & 4581 & 3933 & 10410 & -237 & 914 & $4 \%$ \\
\hline 2013 & 3731 & 11364 & 2593 & 6131 & 1348 & 4277 & 3941 & 10408 & -442 & 279 & $-1 \%$ \\
\hline
\end{tabular}

* Positive numbers mean net imports to domestic market.

**Share of fuels' import in domestic consumption.

Source: PKN Orlen 2013 Factbook, Lotos Data book 30.09.2014, EU Oil bulletin, EIA, POPiHN annual reports, own calculations.

\footnotetext{
${ }^{14}$ Data in the column "net balance of int. trade" in Table 2 come from EIA database (in a case of year 2004 and 2005) and from the POPiHN annual reports for the rest of the sample. One should note that those volumes are not the equal calculated difference between the sum of productions' volumes of both players and the domestic consumption. Unfortunately, there are no detailed export / import volumes of products of our interest divided into player's level. The differences between the calculated volumes and the volumes from the abovementioned sources may result from various reasons, such as conversion from cubic meters to kilo tones, biases in production data of players etc.
} 


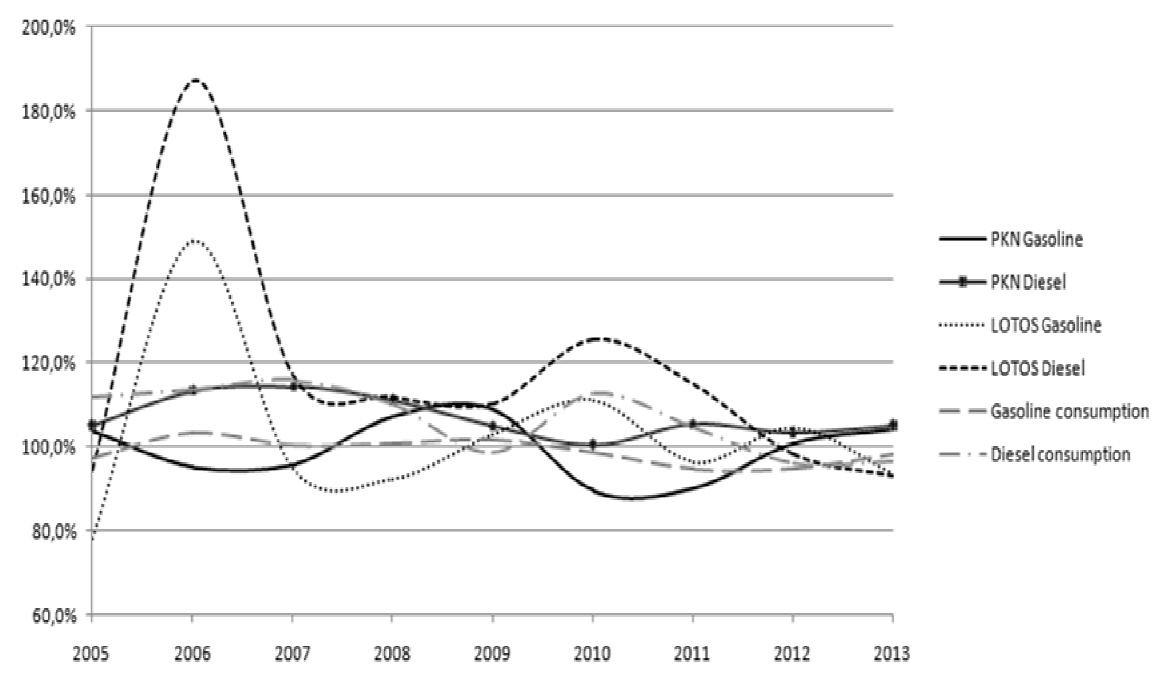

Figure 1. Chain indices - domestic consumption and players' production by type of fuel

Source: own preparation.

\section{CHARACTERISTICS OF THE WHOLESALE FUEL MARKET}

The analysis of the wholesale level of the Polish fuel market should be preceded by several preliminary observations. Potentially, participants in the wholesale market can include companies with refining capacity seeking to supply the market, independent wholesalers, who take a position in the market which is used to supply fuel retailers; oil trading and investment entities, who seek to take advantage of market volatility and arbitrage opportunities, industrial companies seeking to meet their own requirements, such as airlines and shipping companies. Firstly, it can be stated that the Polish wholesale market for unleaded gasoline and motor diesel oil is limited to the first two kinds of players. Quoting the prospectus of Grupa LOTOS $(2014)^{15}$, p.156: "The domestic fuel market is supplied from two sources: domestic producers (PKN Orlen and the Issuer (i.e. LOTOS)) and importers. According to the estimates of POPiHN in 2013, about 91\% of the demand in the Polish wholesale market was met by Polish producers, while the remaining $9 \%$ of the demand was covered by imports (including imports under-

\footnotetext{
${ }^{15}$ Unfortunately, POPiHN calculations used in that prospectus are not available publically as an independent source (see. p.56 of the Prospectus), so we have no such data for the rest of the sample, particularly.
} 
stood as appropriate and intra-EU Community acquisition)." Similar conclusion: "The concentration of the wholesale market for road fuels is very high - the joint share of the two domestic refiners is around 90\%, the remaining $10 \%$ divided among several smaller wholesalers." states DAF/COMP (2013)18 Report (p.243). Secondly, it can be assumed that most of the production of PKN and LOTOS refineries was supplied to the domestic market (wholesale and retail). As can be read in POPiHN annual report (2013): "The main sales market for Polish refineries is the domestic one, which is determined by economic, trade and logistics factors. At the same time, normal foreign trade is continuing, although domestic requirements play a crucial role in stimulating foreign exports. Multinationals operating in Poland, as well as private companies, are also bringing their foreign purchases onto the domestic market, but their share of market supply is only supplementary." Summarizing the above, it can be assumed that:

- the main players of the Polish wholesale fuel market were PKN and LOTOS in a relevant sample period,

- as detailed data on volumes of fuels sold on wholesale level are not publically available, one can proxy those volumes by production of PKN and LOTOS in domestic refineries. This assumption is based on the conclusion that the Polish fuel market was unbalanced by domestic production, and there were no economic, logistic and legal reasons why domestic production was not placed in local (domestic) market,

- even though there were no formal, country specific barriers to entry for wholesalers, it can be assumed that an occurrence of any significant competition to actual incumbents was highly unlikely because of logistics and legal reasons. ${ }^{16}$

The Polish wholesale fuel market can be considered therefore as a duopoly with a minor role of independent traders. From now on, we focus on

\footnotetext{
${ }^{16}$ In February 1997 the Government lifted controls on fuel prices in Poland. The market is open and no import duties or permits are required. However, companies operating in the oil market have to apply for a concession from the Energy Regulations Authority. Granting the concession requires an applicant to assemble valuable security in the amount of 10 million PLN, and pay a yearly fee dependent on the annual income. Additionally, wholesalers active on the domestic market must keep mandatory fuel reserves. The size of mandatory reserves, to be created and maintained by producers and traders, was in 2014 equal to the production of 76 days and the average daily production or import of fuel oil or fuel carried by producer or trader in the previous calendar year. The cost of creating and maintaining the mandatory reserves of crude oil or fuels are met by producers and traders who can allocate them to the cost of operations. The role of company-owned fuel depots and pipelines in creating competitive advantage is obvious in the wholesale level of the market.
} 
the PKN and LOTOS as the major players on that level of the market. It should be noticed that PKN has an advantage in logistics infrastructure. The ORLEN Group uses a network of complementary infrastructure components: fuel terminals, on-shore and off-shore handling terminals, a network of product and feedstock pipelines, as well as road and railway transport. In 2013, pipelines were the key mode of transport for the ORLEN Group's raw materials and products. PKN ORLEN used $379 \mathrm{~km}$ of its own Płock Ostrów Wielkopolski - Wrocław pipeline. For operational purposes related to acceptance, storage, release and handling of fuels, in 2013 the ORLEN Group's logistics operations in Poland used 14 company - owned fuel terminals and depots. The sales processes and wholesale customer service were centralized at subsidiary ORLEN Paliwa Ltd. Grupa LOTOS has a much smaller own infrastructure, with 6 depots. Wholesale operations are provided by direct subsidiary LOTOS Paliwa Ltd.

In order to better understand the circumstances of the Polish wholesale fuel market, one has to look at the retail level as well. Table 3 summarizes the size of retail distribution networks for the main groups of players at the end of 2013.

Table 3. Filling station in Poland (2013)

\begin{tabular}{ccc}
\hline Company & Number of stations & Market share \\
\hline ORLEN Group, including & 1778 & 0.26 \\
PKN ORLEN - CODO & 1338 & 0.20 \\
PKN ORLEN - DOFO & 440 & 0.07 \\
Grupa LOTOS & 439 & 0.07 \\
Foreign concerns, including & 1422 & 0.21 \\
BP & 461 & 0.07 \\
Statoil & 354 & 0.05 \\
Shell & 378 & 0.06 \\
Jet/Lukoil & 116 & 0.02 \\
Hypermarkets network & 166 & 0.02 \\
Other independent stations & 2940 & 0.44 \\
\hline Total & 6745 & \\
\hline
\end{tabular}

Source: PKN Orlen 2013 Factbook.

It can be seen from Table 3 that the two main players in the wholesale sector have a significant share in retail, too. Especially PKN has a strong position in retail (the company estimates the quantity- based market share at $35.4 \%$ in 2013). Unfortunately, according to our knowledge, there are no publically available data from both of the players which separate clearly

\footnotetext{
${ }^{17}$ See: Directors' Report On The Operations Of PKN Orlen In 2013,p.26.
} 
the volumes sold as wholesale from those sold in own retail network ${ }^{18}$. Nevertheless, in order to assess the market structure on the wholesale level in some way, the production volumes allocated in the domestic market were taken as a proxy of volumes of fuels allocated on that level. In doing so, beside the motivation presented earlier, the fact that PKN and LOTOS are the main (and sometimes only) suppliers of fuels for retail (for their own retail networks exclusively) in a domestic market, should be taken into consideration. It is considered that "supply view" is the most appropriate for a description the B2B level of the market ${ }^{19}$. Table 4 presents the estimations of market shares and HHI for such proxies in the two boundary scenarios. The first one, for which both market shares and $\mathrm{HHI}^{* *}$ are depicted in Table 3, assumes that PKN and LOTOS are the only wholesalers on the market (ignores the fringe of $8 \%$ to $10 \%$ representing the sales of independent players), the second one (for which only HHI*** is showed) assumes that all import to domestic market is allocated on the wholesale level by a "third player".

The actual values of HHI are somewhere in between $\mathrm{HHI}^{* *}$ and HHI*** because, on the one hand, the production of major players is not fully allocated in the domestic market ${ }^{20}$ at a wholesale level, and there is an independent set of importers and, on the other hand, PKN and LOTOS have been importers of fuels themselves, so not the whole import is realized by independent players. One can say that the wholesale level of the fuel market was highly concentrated (even if HHI*** is considered) in the sample period, but the market shares of the players indicated some evolutions in time. PKN's share has been rather declining (due to the declining share of diesel supply), while LOTOS' share increased because of the higher growth rate of diesel production. In the same period, it could be noticed that the domestic supply did not fulfill the domestic demand, however, in the case of diesel that was due to real lack of domestic capacities, whereas in the case of gasoline the domestic supply and consumption were almost balanced and in

\footnotetext{
${ }^{18}$ In the case of PKN, the author collected such data for the period of $2005-2014$ (available on request), but one should bear in mind that in 2009 the volumes sold to DOFO stations were reclassified to retail market sales (previously classified to so cold "refinery sector sales" which in organizational structure of PKN means wholesale) and for years 2012 and 2013 aggregations in refining products were done (in reporting of PKN), so sales numbers for gasoline also include LPG (so called "light distillates") and the sales numbers for diesel include JET-A1 fuel and light heating oil (so called "medium distillates"). In the case of LOTOS it was not possible to separate wholesale volumes from retail ones.

${ }^{19}$ The situation in Poland in the sense of domestic wholesale supply control by domestic refineries is very similar to that in New Zealand, as described in Ming-Hua Liu et al.(2010), footnote 4 .

${ }^{20}$ We are not able to precisely divide export volumes by players.
} 
some periods net export of gasoline was the reason for below $-100 \%$ ratio in the Table $4^{21}$.

Table 4. Estimations of market shares and HHI indices

\begin{tabular}{|c|c|c|c|c|c|c|c|c|c|c|c|}
\hline & \multicolumn{2}{|c|}{$\begin{array}{l}\text { net production/ } \\
\text { consumption } \\
\text { ratio* }\end{array}$} & \multicolumn{2}{|c|}{$\begin{array}{c}\text { production } \\
\text { market shares } \\
\text { PKN }\end{array}$} & \multicolumn{2}{|c|}{$\begin{array}{l}\text { production } \\
\text { market shares } \\
\text { Lotos }\end{array}$} & \multicolumn{3}{|c|}{$\begin{array}{l}\text { motor fuels market share } \\
\text { (Gasoline + Diesel) }\end{array}$} & \multicolumn{2}{|c|}{$\begin{array}{c}\text { market share of } \\
\text { import }\end{array}$} \\
\hline & $\begin{array}{c}\text { Gasoli- } \\
\text { ne }\end{array}$ & Diesel & $\begin{array}{l}\text { Gasoli- } \\
\text { ne }\end{array}$ & Diesel & $\begin{array}{l}\text { Gasoli- } \\
\text { ne }\end{array}$ & Diesel & PKN & Lotos & $H H^{* *}$ & & $\mathrm{HHI}^{\star \star \star \star}$ \\
\hline 2004 & $96.4 \%$ & $71.1 \%$ & 0.69 & 0.73 & 0.31 & 0.27 & 0.71 & 0.29 & 0.589 & 0.16 & 0.443 \\
\hline 200 & $93.6 \%$ & 65.0 & & & & & & & & & \\
\hline 200 & 99.9 & & & & & & & & & & \\
\hline & & & & & & & & & & & \\
\hline & & & & & & & & & & & \\
\hline $200 s$ & & & & & & & & & & & \\
\hline 201 & & & & & & & & & & & \\
\hline 2011 & $96.1^{\circ}$ & $84.1 \%$ & 0.6 & & & 0.45 & & & & & 0.387 \\
\hline 2012 & $97.4 \%$ & $88.4 \%$ & 0.63 & & 0.37 & 0.44 & 0.5 & 0 & 0.513 & 0.07 & 0.445 \\
\hline 2013 & $93.8 \%$ & $91.6 \%$ & 0.66 & 0.59 & 0.34 & 0.41 & 0.61 & 0.39 & 0.523 & 0.05 & 0.477 \\
\hline
\end{tabular}

* Domestic production minus export.

** Index calculated on a basis of production's market shares of both mayor players in total domestic net production.

*** Index calculated on a basis of shares of both players' production and share of net import in a total domestic consumption of fuels.

Source: own calculation.

\section{WHOLESALE PRICES - CREATION MECHANISM}

An empirical investigation of the strategic interactions of the players is based on time series of wholesale prices of PKN and LOTOS. In order to understand the 'nature of competition', one should ask how those prices can be theoretically determined, and what information is available publically on such a mechanism. It can be observed that the players officially define their wholesale price policies as follows: $\mathrm{PKN}^{22}$ : 'Fuel prices in Poland are set by the manufacturers on the basis of market conditions controlled phenomena occurring in the global markets petroleum products, the state of the Polish economy and fiscal policies of the state. At the height of the fuel prices affect mainly: taxes on fuel, i.e. VAT and excise duties, the price of crude oil and finished products on world markets ${ }^{23}$, dollar exchange rate, conditions

\footnotetext{
${ }^{21}$ We can't forget about biases in data caused by shadow market influence.

${ }^{22}$ http://www.orlen.pl/PL/DlaBiznesu/HurtoweCenyPaliw

${ }^{23}$ All bold by the Author.
} 
in the domestic market shaped by competition." and LOTOS ${ }^{24}$ :' Daily analysis of: trading prices of fuels and oil in the European markets, the US dollar and the euro exchange rates (published by the NBP i.e. Central Bank of Poland) and the current situation of demand and supply in the domestic market are essential components of the fuel pricing policy of the company." From the above statements, a twofold conclusion can be inferred:

- the pricing mechanism of the players corresponds to well-known Import Parity Pricing (IPP in short) formula,

- both of the player are very cautious to admit this is the case and describe the formula in a more precise way.

Even though there are no publically available players' or competition authorities' documents about parity pricing mechanism in the Polish fuel market, many sources consider that as a fact. As an example, the POPiHN's report 2011, p.24, states:"The prices for liquid fuels in Poland are built on the basis of the so-called import parity, composed mainly of finished fuel trading prices and the US dollar exchange rate and the level of national taxes."

The IPP pricing is based on the assumption that fuel for road use is a tradable good and the ex-refinery price does depend indirectly on the price of crude and of the costs of refining at domestic refineries, but mostly on the price that the purchaser has to pay for this product in a relevant hub plus transport costs and other relevant spreads for the site chosen for storage in Poland. The price so determined is what is commonly termed the import parity price (IPP) corresponding to the price (FOB) in the international markets for fuel for road use, plus transport costs, insurance, discharge and wharfage. Theoretically, the IPP is the maximum level that the domestic producers' wholesale price can reach if there are no obstacles to import. One can point to at least two examples where IPP pricing is officially described as domestic refineries' pricing schema, namely Portugal ${ }^{25}$ and Australia $^{26}$. There is also a significant part of DAF/COMP (2013) report devoted to this policy with some interesting opinion dealing with the influence of this policy on the competitiveness of a market. It is referred to further in the text. In order to define the IPP policy, one has to specify the two key components - the formula itself and the reference price indices. As there are no official

\footnotetext{
${ }^{24} \mathrm{http}: / /$ www.lotos.pl/144/dla_biznesu/hurtowe_ceny_paliw.

${ }^{25}$ Portuguese Competition Authority Report (2009).

${ }^{26}$ Report of the ACCC (2007)
} 
declarations in the case of Polish refineries, a known version of the IPP formula, from ACCC study in this case needs to be adopted ${ }^{27}$ :

IPP based domestic refinery price $=$ a benchmark refinery price + quality premium + shipping costs + wharfage + insurance and loss.

The formula itself is basically similar in different countries, the most important part of the IPP policy definition is a set of benchmark price indices. It can be assumed ${ }^{28}$ that the reference market for Polish refineries is the NWE market represented by Amsterdam - Rotterdam - Antwerp hub. From LOTOS' descriptions of its own model refinery margin one can infer that the benchmark indices for fuels are: PRM UNL 10 ppm CIFARA for gasoline and ULSD 10 ppm CIF NWE for diesel. Both of them are NWE market quotations published actually by Thomson Reuters. As both of the players report their margins in USD/bbl our hypothesis assumed that initial currency for calculation of IPP price is USD. This way, one can avoid problems with the influence of the exchange rate on the price in domestic currency (PLN), as it is assumed that the price in PLN is recalculated by taking (possibly lagged) PLN/USD exchange rate. Moreover, the IPP price is a net price, not including excise tax and fuel duty ${ }^{29}$. The IPP price formula can be simplified in the following way:

IPP based domestic refinery price in USD (gasoline, diesel) $=$ PRM UNL 10 ppm CIFARA or ULSD 10 ppm CIF NWE + spread.

The last important feature of the pricing mechanism is the way in which prices are publically announced. In the sample period, both players announced wholesale prices of various products on their websites. For our purposes, the representative products are: for PKN "unleaded gasoline 95 octane Eurosuper 95" and "motor diesel oil Ekodiesel", for LOTOS "unleaded gasoline 95 octane" and "motor diesel oil EURODIESEL" As those are simply brand names for standard 10ppm products, short names for these shall be further used, PKN PB95, PKN ON and LOTOS PB95, LOTOS ON, respectively. The prices were announced once a day (the exact hour of publishing was evolving during the sample period), but the frequency of the daily announcements was irregular at the beginning of the sample, as depicted in Figures 2 and 3. It can be seen that both players started to publish their

\footnotetext{
${ }^{27}$ Ibid, p. 7.

${ }^{28}$ ARA hub is qualified as reference for north part of CEE region in a Report DGET (2009).

${ }^{29}$ It has to be remembered that wholesalers are direct payers of those duties.
} 
prices in a regular pattern from the beginning of 2006 with regular announcement on weekdays (1 day gap) and with a gap for a Saturday-Monday period (3 days gap).

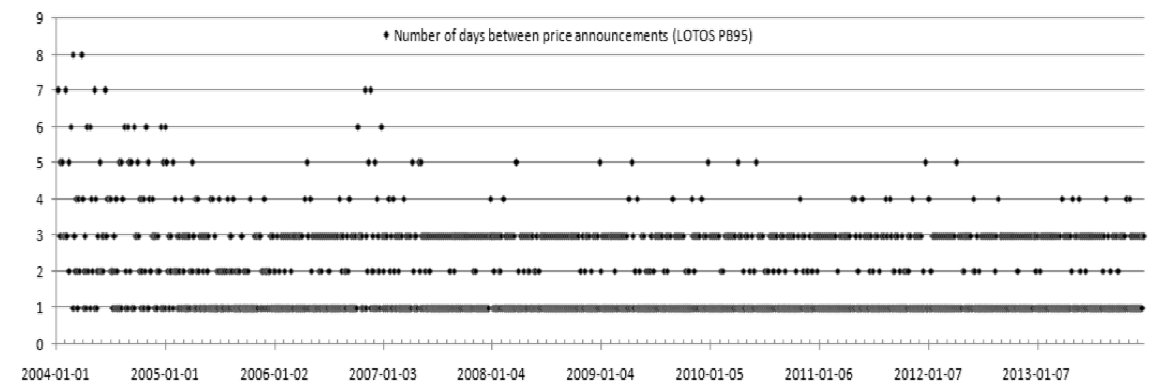

Figure 2. Announcements of wholesale price - LOTOS PB95

Source: own preparation.

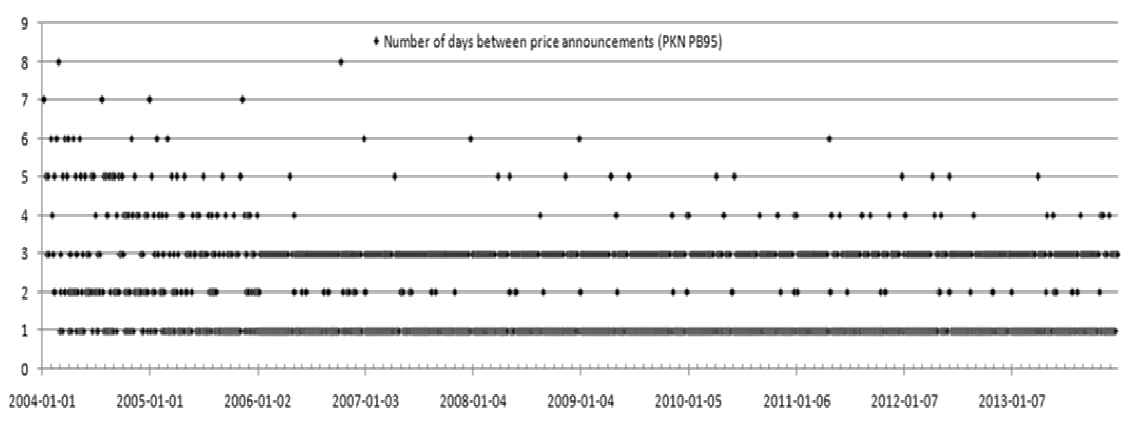

Figure 3. Announcements of wholesale price - PKN PB95

Source: own preparation.

The analysis revealed that both players actually published their prices about midnight day $\mathrm{t}$ for day $\mathrm{t}+1$, and the prices published on Saturdays are valid for Tuesdays, which means that prices are not published on Sundays with validity for Mondays. In order to check the eventual time delay between announcements, which could theoretically allow for observation and adjustment of price by the follower, the precise time of publication of prices should be obtained from both players in the sample period. Unfortunately, it turned out to be impossible. Instead of that, web pages of both players were monitored in randomly chosen periods of time between July $12^{\text {th }}, 2014$ and August $16^{\text {th }}, 2014$. As a result, 22 observations of the exact time of publication of wholesale prices at the players' websites (Table 5) were collected. 
One can observe that the difference in the time of publication does not exceed 11 minutes with the median equal to 7 minutes.

Table 5. Announcement of prices (exact times)

\begin{tabular}{ccc}
\hline Date & $\begin{array}{c}\text { Exact time of price announcement } \\
\text { LOTOS }\end{array}$ & PKN \\
\hline 12-Jul & $11: 59 \mathrm{PM}$ & $12: 06 \mathrm{AM} *$ \\
16-Jul & $12: 00 \mathrm{AM}$ & $12: 03 \mathrm{AM}$ \\
17-Jul & $12: 00 \mathrm{AM}$ & $12: 07 \mathrm{AM}$ \\
18-Jul & $12: 00 \mathrm{AM}$ & $12: 03 \mathrm{AM}$ \\
19-Jul & $11: 59 \mathrm{PM}$ & $12: 10 \mathrm{AM}$ \\
22-Jul & $11: 59 \mathrm{PM}$ & $12: 01 \mathrm{AM}$ \\
23-Jul & $11: 59 \mathrm{PM}$ & $12: 06 \mathrm{AM}$ \\
25-Jul & $11: 59 \mathrm{PM}$ & $12: 08 \mathrm{AM}$ \\
26-Jul & $11: 59 \mathrm{PM}$ & $12: 02 \mathrm{AM}$ \\
29-Jul & $12: 00 \mathrm{AM}$ & $12: 08 \mathrm{AM}$ \\
31-Jul & $11: 59 \mathrm{PM}$ & $12: 10 \mathrm{AM}$ \\
1-Aug & $12: 00 \mathrm{AM}$ & $12: 00 \mathrm{AM}$ \\
2-Aug & $12: 00 \mathrm{AM}$ & $12: 00 \mathrm{AM}$ \\
5-Aug & $12: 00 \mathrm{AM}$ & $12: 09 \mathrm{AM}$ \\
6-Aug & $11: 59 \mathrm{PM}$ & $12: 08 \mathrm{AM}$ \\
7-Aug & $11: 59 \mathrm{PM}$ & $12: 08 \mathrm{AM}$ \\
8-Aug & $12: 00 \mathrm{AM}$ & $12: 06 \mathrm{AM}$ \\
9-Aug & $12: 00 \mathrm{AM}$ & $12: 05 \mathrm{AM}$ \\
12-Aug & $12: 00 \mathrm{AM}$ & $12: 11 \mathrm{AM}$ \\
13-Aug & $12: 00 \mathrm{AM}$ & $12: 01 \mathrm{AM}$ \\
14-Aug & $11: 59 \mathrm{PM}$ & $12: 09 \mathrm{AM}$ \\
16-Aug & $12: 00 \mathrm{AM}$ & $12: 04 \mathrm{AM}$ \\
\hline
\end{tabular}

* AM - means publication after midnight.

Source: own preparation.

The observation which is also worth noticing is connected with the grid of prices. It was observed that all values of the prices in a sample period were integer numbers. Empirical distributions of price's grid of PB 95 (as an example) in sample period are summarized in Table 6.

Table 6. Price's grid of PB 95

\begin{tabular}{ccc}
\hline LOTOS PB & & PKN PB \\
\hline $\mathrm{n}$ & grid* (PLN) & $\mathrm{n}$ \\
\hline 561 & 1 & 799 \\
626 & 2 & 881 \\
1156 & 5 & 601 \\
2343 & Total & 2281 \\
\hline
\end{tabular}

* Grid is a the biggest prime number divisor of a wholesale price.

Source: own calculation.

AUNC, EKONOMIA XLVI nr 1 (2015) 77-95 


\section{CONCLUSIONS}

The main objective of the study was to extract, describe and interpret the key characteristics of the Polish refining industry, the wholesale level of a domestic fuel market and the players involved in strategic interactions on that level.

The study has analyzed the structure of the Polish petroleum industry (refining sector) and the wholesale level of the market at first, to extract every factors influencing the shape of theoretical strategic interaction model. At that stage of the research, it was concluded that:

- refining industry has been a duopoly with players' market shares in terms of processed crude roughly in proportion $2 / 3$ to $1 / 3$. HHI index of refining has equaled 0.538 on average in the sample period which is very high (Central and Eastern Europe region HHI of complex capacity in 2009 was equal 0.1624 for comparison),

- the capacities of both players have increased systematically and reached the growth rate of $21 \%$ in the case of PKN, and $133 \%$ in a case of LOTOS in a sample period. Such a trend was in contrary to the European tendencies, where since 2009 several refineries, with a combined processing capacity of $3.7 \mathrm{~m} \mathrm{bbl} / \mathrm{d}$, have been closed down. Capacity utilization was very high in the case of both players (on average $96 \%$ and $94 \%$, respectively), despite the investments, so one can say that the production of both players was capacity - limited,

- after investigation of wholesale fuel market, the Polish wholesale fuel market was considered as a duopoly with a minor role of independent traders,

- the Author found the wholesale level of the fuel market to be highly concentrated with $\mathrm{HHI}$ in the range of 0.410 to 0.546 on average. In the sample period, it was noticed that domestic supply did not fulfill domestic demand in case of diesel, due to real lack of domestic capacities, whereas in the case of gasoline the domestic supply and consumption were almost balanced,

- PKN had strong vertical integration with the retail level, which could be an important factor for wholesale level strategic behavior,

- the wholesale price creation mechanism was studied, the conclusion being that the pricing mechanism of the players corresponds to the wellknown Import Parity Pricing (IPP in short) formula. The price levels were publically announced by both players on their websites from the beginning of the sample period, but regular patterns were being noticed 
from the beginning of 2006 with announcement on weekdays and with a gap for the Saturday-Monday period.

On the basis of the research, important factors influencing strategic interaction of market participants can be enumerated:

- duopolistic market with high concentration,

- homogenous products ${ }^{30}$,

- high barriers to entry,

- no threats of significant entry to the market in the sample period,

- capacity constraints for domestic production,

- inelastic demand ${ }^{31}$,

- type of pricing mechanism and price transparency.

Basing on these characteristics, one can point to essential elements of a theoretical model of strategic interactions (game model) which should be constructed as a source of a pattern of behavior of the players:

- price as a strategic variable for players,

- high probability of existence of common ceiling (focal) level of price (IPP price),

- fixed number $n$ of players in a game horizon $(\mathrm{n}=2)$,

- capacities treated as exogenous parameters in the game horizon,

- single period of a game should be modeled as an non-zero sum, simultaneous moves finite game in pure action spaces.

\section{REFERENCES}

Abrantes-Metz R. (2011), Design and Implementation of Screens and Their Use by Defendants, "CPI Antitrust Chronicle (2)".

Abrantes-Metz R. (2013), Pro-active vs. Reactive Anti-Cartel Policy: the Role of Empirical Screens, ,SSRN Electronic Journal”, 1-28.

Adamczyk A., Witkowski P., Putek-Szeląg E. (2014), The fiscal and stimulus functions of the excise tax for motor fuels in Poland, ,Zeszyty naukowe Uniwersytetu Szczecińskiego" nr 818, Finanse, Rynki Finansowe, Ubezpieczenia, 68.

${ }^{30}$ It is assumed that gasoline and diesel from both sources (either from own refining or from import) fulfill technical and quality norms, which are standardized and well-defined by EU regulations. We, therefore, consider products as indistinguishable for the buyers at the wholesale level.

${ }^{31}$ Income and price elasticities of demand for liquid fuels have been a subject of research several times. As an example, Kyoung-Min Lim et al. (2012) presented an up to date summary of the body of research on diesel and gasoline. One can learn from the previous papers that short-ran price elasticity was very low worldwide (the average of OECD countries estimated from -0.16 to -0.24 , for other countries -0.2 is a typical threshold). Long run price elasticity estimated values are a bit higher, but still well below -1 . In the case of Poland in Adamczyk et al. (2014) the authors estimated the price elasticity of demand for gasoline at retail level. Their estimation was $-0,1$ for the period of 2003-2012. 
Bejger S. (2009), Econometric tools for detection of collusion equilibrium in the industry, „Dynamic Econometric Models”, 9, 27-38.

Bejger S. (2015), Theoretical model of pricing behavior on the Polish wholesale fuel market, Univeristy of Szczecin, forthcoming.

DAF/COMP (2013), Competition in road fuel - executive summary of that debate and the documents from the meeting, Organisation for Economic Co-operation and Development, 18.

Detailed analysis of the liquid fuel and bottled gas sectors in Portugal Final Report, Portuguese Competition Authority (Autoridade da Concorrência), March 2009.

Directors' report on the operations of PKN Orlen in 2013.

Grupa LOTOS Annual Report, years 2004-2013.

Integrated Annual Reports, years 2004-2013, Grupa LOTOS S.A.

Kyoung-Min L., Myunghwan K., Chang Seob K., Seung-Hoon Y. (2012), Short-Run and Long-Run Elasticities of Diesel Demand in Korea, „Energies”, 5, 5055-5064.

Ming-Hua L., Margaritis D., Tourani-Rad A. (2010), Is there an asymmetry in the response of diesel and petrol prices to crude oil price changes? Evidence from New Zealand, „Energy Economics", 32, 926-932.

Perloff J. M, Karp L. S., Golan A. (2007), Estimating market power and strategies, Cambridge University Press, Cambridge NY.

Petrol prices and Australian consumers: Report of the ACCC inquiry into the price of unleaded petrol, December 2007.

PKN Orlen Annual Report, years 2004-2013.

PKN Orlen Fact Book, years 2004-2013.

Prospectus of Grupa LOTOS, 2014, Grupa LOTOS S.A.

Survey of the competitive aspects of oil and oil product markets in the EU (2009), A report to Directorate-General Energy and Transport of the European Commission.

The Polish Oil Industry and Trade Organisation Annual report, years 2007-2013.

Tirole J. (1998), The Theory of Industrial Organization, The MIT Press, England. 